\title{
Experience and Expectation of International Students: Over Barclays Bank, Service Quality in Chester, UK
}

\author{
Ms Joyce Yeoward, Mr Prapul Kumar Ashwathnarayana \\ Faculty \\ Centre for Management Studies \\ Madan Mohan Malaviya University of Technology, Gorakhpur
}

\begin{abstract}
In the $21^{\text {st }}$ century service industry has grabbed and changed the phenomenal look of the business market, as service is an endless endeavor of any product, which is delivered as soon the product is launched in the market, and people are more depended on services, which has become an essential needs for them. When service is delivered to the customer the services providers' has to maintain the quality of services, which might be beyond the expectation of the consumers, which will lead in a better level of satisfaction and elevate the organizations reputation. In the banking sector the main expectation of the customers is assurance, reliability, responsiveness taken by the bank, if the consumers are pleased by the services, then the bank accomplishes the purpose of satisfying the customer and delivering all their needs. In this research the researcher has considered the aspects of satisfying the expectations of customer, through the values of services quality and to understand the gap between experience and expectation by adopting SERVQUAL model and gap analysis, these helped the researcher to showcase the services quality provided by the Barclays bank Chester to the international students. By adopting the above model the researcher has conferred that the services provided by the Barclays bank has tried to satisfy the customer and the overall gap of expectation and satisfaction has showed positive score of $(+2.26)$ this also describes that by providing more better and quality services, the customer satisfaction score can be improved. This also can be observed in future by carrying out other research programs on the same topic on larger demographic or international scale.
\end{abstract}

\section{Introduction}

The primary objective of an organization is to achieve customer satisfaction by delivering qualitative service (Gungor, 2007). In today's era of development, business environment is characterized by change in technology, product, evolution, customer expectations and also in political development. It also Introduces to ICT i.e. (information communication technology), which is one of the fastest growing technology in the service sector, and one of the most leading worldwide service sectors (Abor, 2005).

In the present century banking sector had calmed an essential place in the international economy, the major changes is to adopt technology into this sector which expanded the utilisation of the banking sector which attracted and increased the customers (Bryan \& Wang, 2014).

Muntermann (2007) stated that about 4 electrical commerce actions are implement in Internet operator. Accomplishments are usually requisite of the banking relationship, investing, online shopping, banking payments, etc. (Dale, Wiele \& Iwaarden, 2013).

\section{Company History (Barclays)}

John Freame founder of the Barclays bank in the year April 1690, his first branch was set up in Lombard streets, London. He started his business with two servants and a partner named Thomas Gould. Later in the year 1896 Barclays was merged with the Gosling bank, the three squirrels resembled its logo is even seen in Fleet Street today on Barclay's branch. Then later joined David Barclay, the sixth generation descendent of John Freame made a enterprises of a new limited company with Barclays and co-formers today called Barclays Bank private limited (Ackrill \& Hannah, 2001). 


\section{Research Questions And Aims:}

The research subject chosen to the study is "experience and expectation of international students: over Barclays bank service quality in Chester".

The main object of selecting this area of study is to investigate the service quality level by adopting SERVQUAL method to international students in understanding the expectation and experience with Barclays bank Chester. The researcher will be gathering secondary information from book, journals and the foregoing master's thesis for prominence the concept, also the researcher will be showcasing the gap among the services provider and their customers, and referring the appropriate result to fill those gaps. The research aims are illuminated below as:

Identifying the GAP between services expected and services received by an international student in Chester from Barclays bank.

$>$ The measuring service quality of the Barclays bank in respect to their services provided to international students in Chester.

\section{Literature Review}

\section{Customer Expectation And Perception Of Service Quality}

According to Zeithamal, Parasuraman and Berry (1990) customer expectation be presented by the quality of service which includes the principles of the service quality models. The Service quality model explains the gap between the consumer's expectations of service quality also the customer's experiences of service quality. Expectation is supposed to be a part of service quality, which bring out the gap between customer experiences and what they actually receive, this is measured on the base of exceptional service, satisfactory service and unsatisfactory service. When in reality the given service meets the expectation of the customer the outcome of the services is always positive and it maintains a good relationship therefore a representation of an excellent service which the customer always expected when the perception of the service fails to meet the service expected then the outcome is the unsatisfactory service which in return makes the customer disappointed by the service.

According to the Kotler (2000) service is tangible as it is performances and the individual experiences of the customer, when it is linked to banking performances frequently varies from services providers to the customer and to the present day to day context, It is problematic to abstract the service by putting it a time shell then analysing and retesting it numerous period. Service production is inseparable from consumption. For instance, it is hard to regulate and keep up the consistency of the quality of interfaces between customers and cashiers. Consumers anticipate expectation that makes to look forward or predict about service quality, and therefore it influences the estimation of the service as soon as it is expected, "if you expect little or nothing... then the simple fact of being listened to can produce rapturous satisfaction" (Gaster, 1995). Retaining the previous service encounters will be able to outline expectation as a uniqueness and strength of the data can make some factual data more easily evoked. Previous, positive or ineffective services received can influence expectations of consumers (Rust and Oliver, 1994).

However, there are some behaviors which might remain monitored by customers toward their anticipation of service excellence, intellectual compounds, approximately unassuming, individually observed expectations remain swayed by consumer individual understandings and views then by their skill and enthusiasm toward the use of several kinds of evidence. The debate about a service based credibility will remain uncertain, since it is challenging to assess and take a significant outcome of the opinion on the penalties in unachievement might occur (Ostrom and Iacobucci, 1995). Therefore customer's expectancy for service quality is fairly altered on the bases of providers who have confidence in (Rust and Oliver, 1994).

\section{The Relation Among Service Quality and Expectation}

Service quality and customer expectation the share closest place and they are interrelated with each other as they are measured as a design of numerous researchers (Oliver, 2010); Patterson \& Johnson, 1993). Spreng 
and Mackoy (1996) confirmed Oliver (1993) model, which describes the incorporation of both concepts and that observed services quality is the predecessor of satisfaction.

Customer satisfaction is an essential concept in service groups as it is more correlated to service quality, to satisfy the customer satisfaction the better quality of services has to render and by providing this level of satisfaction which is repeatedly increased in the commitment in taking or utilization of service (Vinten, 2005).

Delvin, Dong, and Brown (1993) stated that service which is provided by an organization, business might be calculated by knowing satisfaction of a customer by the use of service quality measures. The key elements that are being motivated by the level of consumer satisfaction and service quality are the strategic marketing variables and they are as follows, optimism in spreading and being influenced by word-of-mouth, firm productivity, a buyer's allegiance, and intent to yield, faith and assurance (Anderson, 1998).

Figure: The Gaps model of service quality

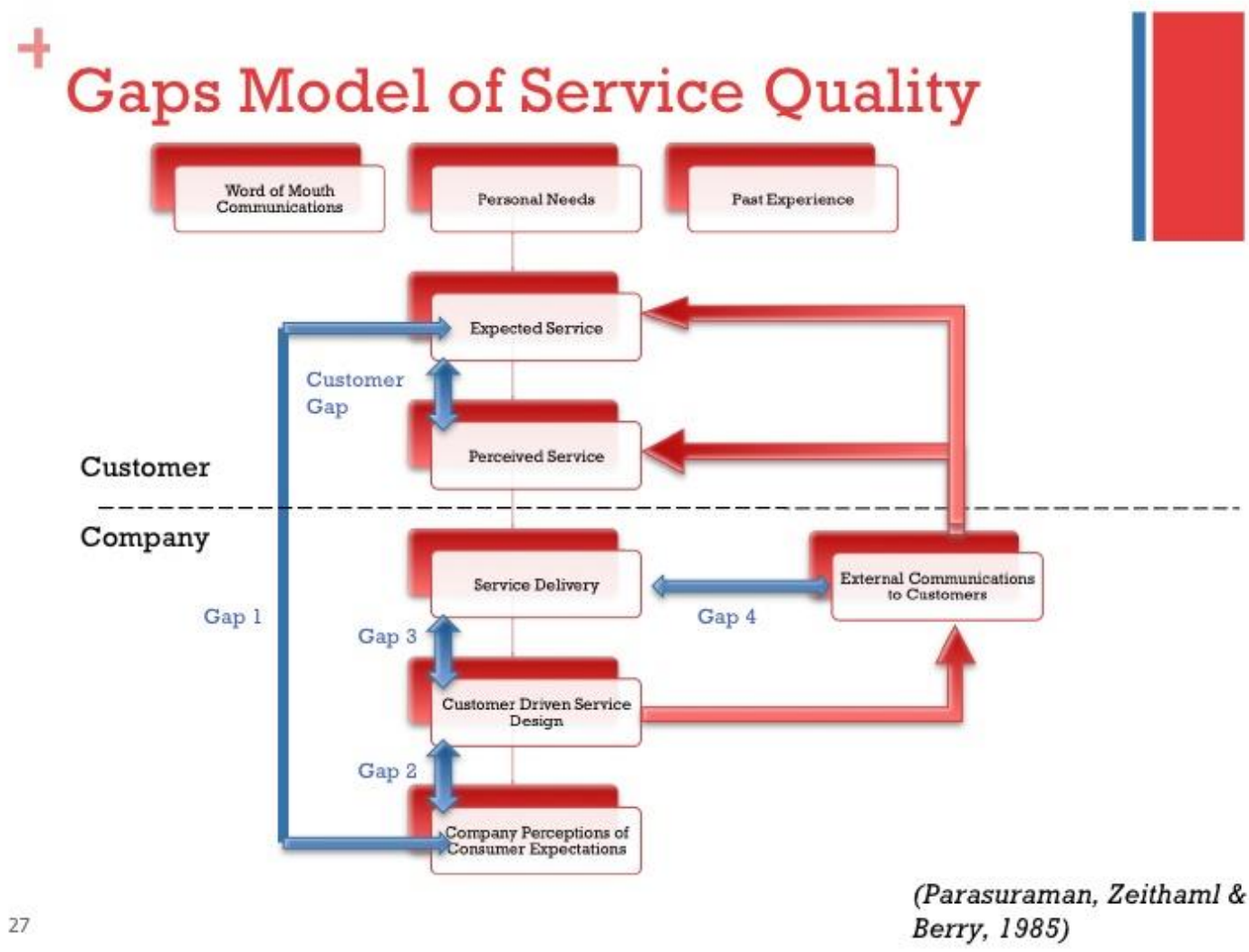

Source:

https://www.google.co.uk/search?q=conceptual+model+of+service+quality\&es_sm=93\&tbm=isch\&tbo=u\& source $=$ univ\&sa $=$ X\&ved=0CDEQsARqFQoTCJXJ6pDsxcgCFUldGgod0EYKKw\&biw=1034\&bih=875\#i mgrc $=0003$ OUSIXzJ-wM\%3A

According to Hernon \& Altman (1998) the main purpose of retaining an effective connection with the customer is to recognise the customer satisfaction and it also delivers more control over the organisation to appreciate the relation rather than just holding a business relation. He also describes "that company which operating its business by not understanding customer satisfaction is similar to a company not holding financial or accounting analysis". Every business or an organisation need to hold significance in customer satisfaction as it is essential to satisfy the customer minds, providing the required necessity will deliver assurance in the minds of the customer on the service expected and gathering statistics for facilities received by a customer will help us to know the necessary improvements to be made in further and it also enhances the relation between each other. 


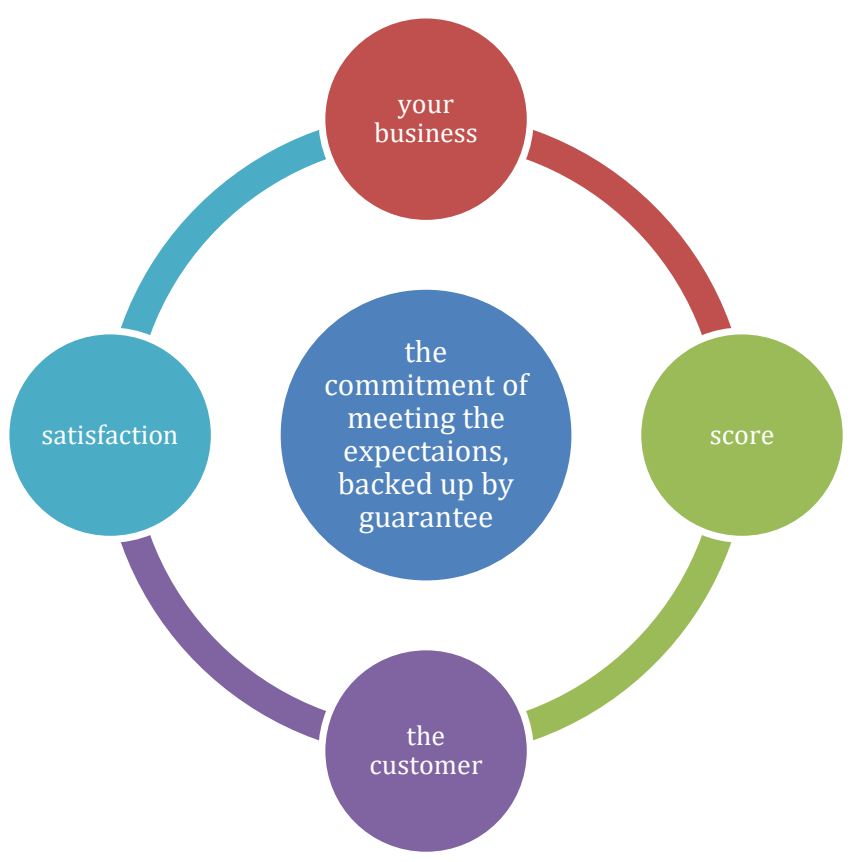

Source: Hernon \& Whitman, (2001) delivering satisfaction and service quality

\section{Retail Banking}

The process of retail banking that is referred in banking sectors as services provided by the bank to individual customers, which includes the process of payment and money such as the cheque, ATM, debit cards retail banking excludes business banking and its financial relegated products categorised under investment and transactions of financial products which can be classified as credit cards, loans, overdrafts and insurance relegated services. In the banking sector, retail banking is a mature sector, which are processed in the similar product line. Strategies in marketing are a mature process for every product line stage, which contains a modified market, price and product. Marketing mix of this line of the product is made as a process of evolution of a new banking market, based on the ideology to create a new market within this segment and to attract new customers and to provide banking in all places such as supermarkets, shopping centres, etc. in an effort to enlarge the banking sector and its marketing mix (Kotler, 2000).

The main objectives of the retail banking is to provide sustainable and more customer friendly services to make them more comfortable with every service and loyal relationship. The banking sector has made various and rapid change in service provider over years, when compared to the mature market, retail banking has made more noticeable changes with ab objective to compete with the banks in a growing market. (croxford, Abramson \& Jablonowski, 2005). With the use of relationship marketing the value or cost of retaining a new customer in the banking service is five times more than maintaining a current customer Reichheld and Sasser (1990).

Retail banking is basically a huge banking market and its main function or to present services to individual banking customers with savings, depositing, and other various services. The services provided depend on the nature of account the customer is registered for, and depositing, transferring money, loans, mortgages, debit and credit cards. The latest channels of distribution in retail banking sectors are branch network, automated teller machines (ATM's), Internet banking, and mobile banking all these changes are the innovation which ensures the loyalty and relationship with customers with a variety and time saving services to their customers (Essvale Corporation Limited, 2007).

According to Violano \& Van Collie (1992) the change in financial industry sectors over the years considering the "McBanking" phenomenon in 1980s, two well-represented banks made mergers and called 
it as retail banking. This process compelled various other banks to make changes to pace up with Mcbankers. In order to increase sales, bankers need to understand the customers and convincing the customer. This is a long process and ensures success and development of the bank. To achieve this communication between banker and customer was the solution. By interacting with the customer, bankers were able to overcome and find a solution to the problems faced by their customer friendly by adapting technology, development of custom. All these changes aided to the development of retail banking.

\section{Servqual}

Gilmore (2003) agreed that service is the most necessary part of living, which as linked to every day to day pulmonary accepts to us. As we use a lot of services through daily life, the service, which is received to us, has to be satisfied to make the service meaningful. Some famous authors of marketing recognize service to be highly significant as it fills the gap in certain marketing measures or principles.

The gap model was introduced in the year 1984 to measure the quality of the services which is processed to the customer this model is recognised as SERVQUAL model and it is constructed and designed by Parasuraman, Zethaml and Berry (Garten, William, Nyce \& Golden, 2008). The main function to design this model is to understand the services quality and it can be used and adapted in any situation in the organisation or business to understand or measuring service quality. This model describes the 22 designed model and ten dimensions on which it will distinguish the gap between customer expectation and experience of the services received, in later years to understand the dimensions of quality measures it is broken down to five dimensions which are showcased in the figure below (Parasuraman et al., 1998)

Figure: SERVQUAL model
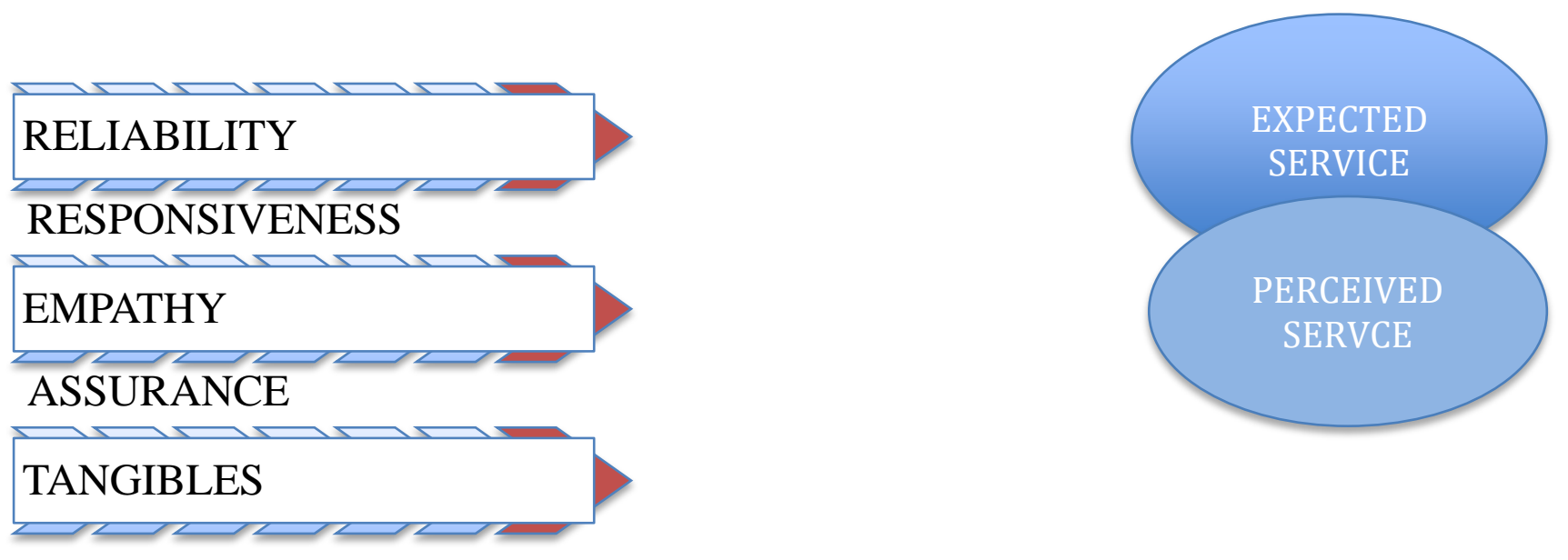

Sources: Parasuraman, A., Zeithaml, V., \& Berry, L. (1988). SERVQUAL: a multiple-item scale for measuring customer perception of service quality. Journal of retailing, 64(1), 12-40

As noted in Evangelos \& Yannis (2009), this model is recognised as a better approach to find the service gap between the experiences and satisfaction faced by the customer in the process of receiving the service. Understanding in detail within the banking sector, Avkiran (1994) made several measures to find out service quality which are received by the customer, and their measures are made to analysis expectations which was there before receiving the service, by adopting 21 measures on the bank's customer and employees which were closing to understand the mistakes are the problems which was faced by those banks (Newman and Cowling, 1996).

According to Wang et al. (2003) SERVQUAL method is used in most of the banking sector to understand the service quality and this model is mainly used in the developing country in improving and make the banking sector more advance in operating functions, by understanding the customer's review whether the customers are satisfied with the bank services provided. When the service provided by the company or the organisation matching to their customer expectation, which explains the services provider is providing 
adequative services to its customer to match its customer needs (Caruana 2002), as the reason SERQUAL model is applied in all the service, service providing sectors like the education institute, travel and tourism services, the banking sector, etc. to know their level of services provided to their customer (buttle, 1996; Crouch, 2004)

As like other topics SERVQUAL also hold critics on its results and major parts are in the length of the questionnaire which has to be implemented to investigate and realise the gap between the expectation and experience and the main drawback in the questionnaire which are repeated and which also the backdrop to the model. The above five dimensions which are showcased are used to frame the question in the SERVQUAL method, but it is argued that these are not used for statistical data interpretation, the validity of this dimension over being an instrument for quantitative research or a measurement tool has been questioned tremendously (Wirtz, Chew \& Lovelock, 2012).

\section{Gaps of Service Quality in The Banking Sector}

The tool which was designed by Zeithaml, Parasuraman and Berry (1990) to understand the problems caused, or the gap which made the customer to lose the quality relationship, in the process of expectation and experiences of customer services are measured by this particular gap model from the organisation and also by calculating the measures to overcome the service quality problems to gain the growth in their market.

Figure 2.4: The gap model of service quality

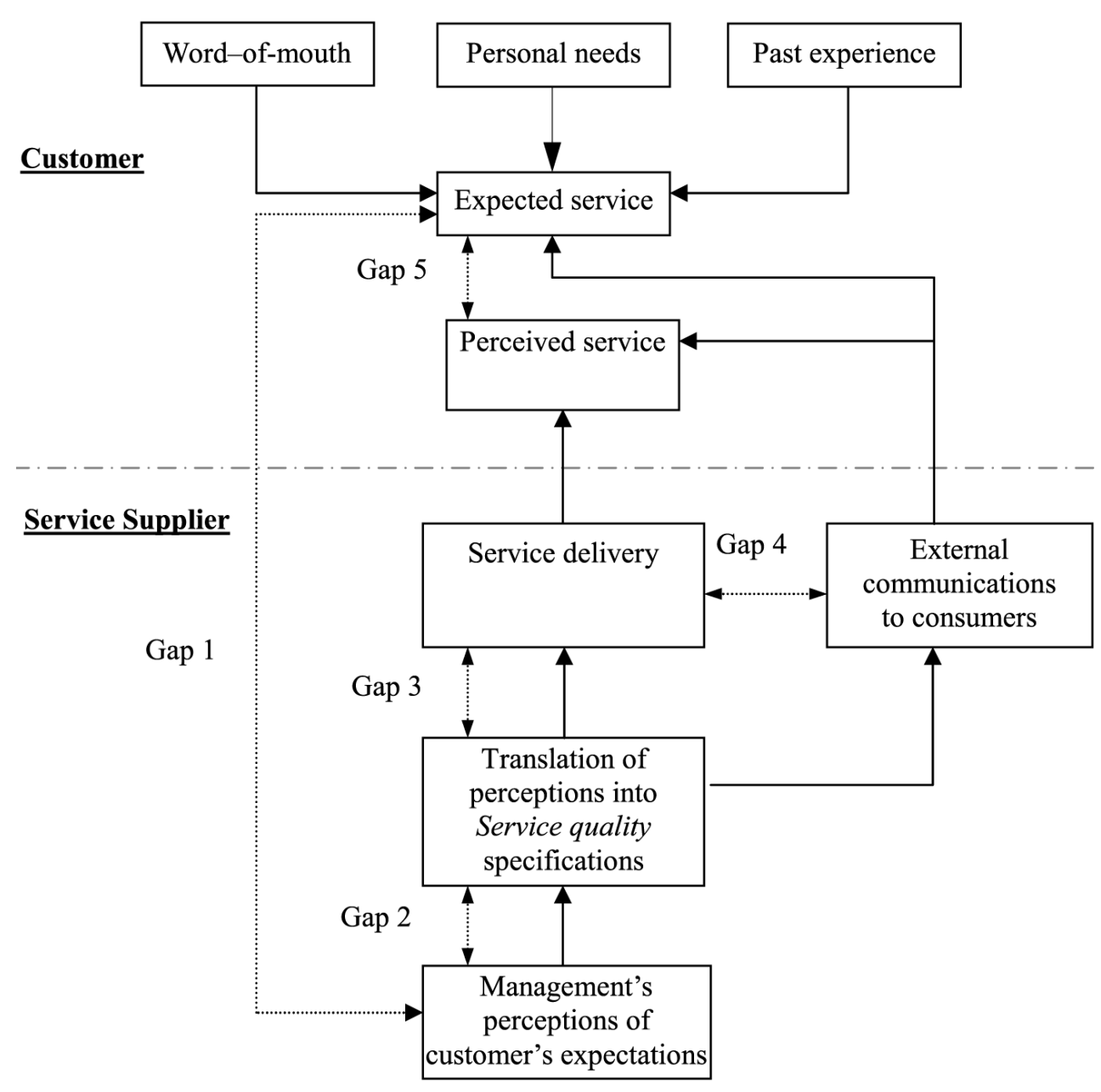

Sources: http://demandsideanalytics.blogspot.co.uk/

Gap 1: Customer expectancy and perception of the organizations on this expectancy: 
The customer expectancy in the service quality which are provided by the organisation, which is the gap in organisation perception and the organisation perception varies, as the expectancy depends on the assurance given by the organisation or the services that has gained in the process of previous experiences, word of mouth. The main problems in dissatisfaction of the gap are less communication among organisation and customers, less interaction among the higher level of management in gaining the customer needs and requirement (Gronroos, 2007).

Gap 2: Management observations of customer expectation

This gap is among the service provider and service receiver (customer), this gap comes into action at the process of services provider fails to meet the requirement of the customer, and the main problems in the gaps are no proper development of planning on the customer service requirement and not understanding the present market restraints (Lamb et al., 2001).

Gap 3: Specification in service quality and service delivery

The gap is caused due to the incompletion of the staffs work and the performances of work that is been performed by the administration also failed meet the expectation, the problems are mainly in the internal factor in the management are caused due to poor performances by the staffs, tanning department, and no proper supervision of the work (lamb et al., 2011, Gronroos, 2007).

Gap 4: Service delivery and external communication to customer

The gap is among service distributing and communication of delivering the service which are assured to be delivered. This gap is caused due to no proper communication between the levels of management, over auspicious in service delivery (lamb et al., 2011, Gronroos, 2007).

\section{Gap 5: Expected service and supposed service}

This gap is frequently see in the service based organisation, as the customer is expected that the service would be extreme, but when that doesn't happen this gap arises between the customer and service provider. The problems faced in the particular gap are damaging the impression with the customers, the reduction of service delivering (Gronroos, 2007).

The complications in service are caused by the banking sector in the process of satisfying its customer is developed by having the gap between customer experiences and expectation, as this are the main tool to the bankers to make them successful in their sector. When the customer gets unexpected services that would make them happy for the services received, it will also increases the gap in favourable to the bank. If there is a reduction in terms of services then it goes down wards which would be unfavourable in terms of the relationship gap with the bank (Boone and Kurtz, 2000).

Table 2.1: According to Hoffman and Bateson (1997) there are few gaps between consumer expectation and perceptions, which are as follows:

\begin{tabular}{|l|l|l|}
\hline Gap 1 & Kap name & Expiation of the Gap \\
\hline Gap 2 & Standard gap & $\begin{array}{l}\text { Variance between the expected service by the } \\
\text { customers and the service observed to be expected by } \\
\text { the management }\end{array}$ \\
\hline Gap 3 & Delivery gap & $\begin{array}{l}\text { Variances in the level of standard set by the service } \\
\text { the consumer }\end{array}$ \\
\hline Gap 4 & $\begin{array}{l}\text { Communiances between the Set of quality services which } \\
\text { gap stated by the service provider and services } \\
\text { delivered in reality }\end{array}$ \\
\hline
\end{tabular}

Practical Application Of Service Quality In Banks: 
According to Domingo, (2003) total quality management, (TQM) which is applicable to not only to manufacturing units but also service industries where customers are equally valuable, this tool is used for the full consumer service and constant customer satisfaction. The Consumers are more complex in the services they receive and its quality in a service sector as it is a face to face encounter with these consumers other than those workers or staff in factories.

Domingo, (2003) also adds that the banking sector benefits from TQM roles, a bank which applies TQM should have aims and standards for customer satisfaction like: dispensation time of transactions, and core services for example, fresh accounts, loan sanctions, encashment and debit, credit cards, managing line, waiting areas, handling verbal and written complaints, the good attitude of employees, general interest rates, tedious statements of past or lost records and accounts. Keeping such goals can serve in improving and gaining customer satisfaction and loyalty.

All private sectors have a huge budget for training and development, like the airlines same in the banking sector as well, that is why it has been expected for these organisations to do well in the part of delivering effective service, therefore there should be efficient utilisation of this sum.

\section{Analysis Of Respondents And Nonrespondents}

The data obtained of the particular research analysis are primary data by the use of survey method or questioner, this particular questionnaire is adopted by the use of the SERVQUAL model and the questions are divided into 5 parts and 21 questions were framed according the model to analysis the gap, totally 80 international students who had an account with the Barclays bank participated in the survey and the questioner was circulated to them. The responded international students were 50 and non-responded students were 30, due to a lesser amount of time and reluctance of the respondents to fill the questioner. Totally 50 questioners are considered to research for the further calculation of mean, median and standard calculation.

\section{Findings}

\section{Ethnicity of respondents}

\begin{tabular}{|l|l|l|}
\hline & Nationality & No of Respondents \\
\hline $\mathbf{1}$ & Afghanistan & 2 \\
\hline $\mathbf{2}$ & Algerian & 1 \\
\hline $\mathbf{3}$ & Brazilian & 1 \\
\hline $\mathbf{4}$ & Cameroonian & 2 \\
\hline $\mathbf{5}$ & Chinese & 4 \\
\hline $\mathbf{6}$ & Ghanaian & 4 \\
\hline $\mathbf{7}$ & Indian & 12 \\
\hline $\mathbf{8}$ & Indonesian & 3 \\
\hline $\mathbf{9}$ & Italian & 1 \\
\hline $\mathbf{1 0}$ & Malaysian & 3 \\
\hline $\mathbf{1 1}$ & Palestinian & 2 \\
\hline $\mathbf{1 2}$ & Pakistani & 2 \\
\hline $\mathbf{1 3}$ & Turkish & 3 \\
\hline $\mathbf{1 4}$ & United Arab Emirates & 3 \\
\hline $\mathbf{1 5}$ & Uzbekistan & 2 \\
\hline $\mathbf{1 6}$ & Vietnamese & 5 \\
\hline Total & & 50 \\
\hline
\end{tabular}

The above table (4.1) explains the number of respondents participated in the survey on the basis of their nationality it has been mentioned in numbers.

\section{Gender}

\begin{tabular}{|l|l|l|l|}
\hline $\mathbf{1}$ & Gender & Frequency & percentage \\
\hline $\mathbf{2}$ & Male & 23 & 48.19 \\
\hline
\end{tabular}


The above table (4.2) shows the total number of male and Female respondents who took part in the survey are mentioned, 23 male (48.19 percent) and 27 female (51.81 percent) respondents, in total 50 respondents (100 percent).

Age

\begin{tabular}{|l|l|l|l|}
\hline & Age group & Frequency & Percentage \\
\hline $\mathbf{1}$ & $20-25$ & 42 & $84 \%$ \\
\hline $\mathbf{2}$ & $25-30$ & 8 & $16 \%$ \\
\hline
\end{tabular}

The above table (4.3) the respondent age group and 84 percent of respondent were 20-25 age and 16 percent of respondent were 25-30 age.

\section{Case processing summaries}

\begin{tabular}{|l|l|l|}
\hline Cases & Respondent & Percentage \\
\hline Valid & 50 & 100 \\
\hline Excluded & 0 & 0 \\
\hline Total & 50 & 50 \\
\hline
\end{tabular}

The above table (4.4) explains the total number of respondents and the questionnaire were valid, the total number of questionnaire circulated were 80 but due to a lesser amount of time and reluctance of the respondents to fill the questioner the researcher could not receive back those 30 questioners, the left 50 question which was collected back after responding were truly valid.

\section{Reliability statistics}

\begin{tabular}{|l|l|l|l|}
\hline & $\begin{array}{l}\text { Cronbach's } \\
\text { alpha }\end{array}$ & $\begin{array}{l}\text { Cronbach's } \\
\text { Alpha based on } \\
\text { standardized } \\
\text { items }\end{array}$ & N of items \\
\hline Expectation & 0.978 & 0.978 & 21 \\
\hline Expectation & 0.898 & 0.901 & 21 \\
\hline
\end{tabular}

The above table (4.5) shows the reliability statistics which explains the Cronbach's alpha calculation, the Cronbach's alpha explains the reliability of the questioners, if the Cronbach's alphas greater than 0.920 then the research is reliable, in this particular the researcher has scored 0.978 which shows the research is liable and also shows that the SERVQUAL model is reliable to the research.

In the below table the 'Ex' refers as expectation and 'Ep' refers as experiences.

\section{Summary item statistics}

\begin{tabular}{|c|c|c|c|c|c|c|c|c|c|c|}
\hline & \multicolumn{2}{|l|}{ mean } & \multicolumn{2}{|c|}{ Minimum } & \multicolumn{2}{|c|}{ Maximum } & \multicolumn{2}{|l|}{ Range } & \multicolumn{2}{|c|}{ Variance } \\
\hline & Ex & Ep & Ex & Ep & Ex & Ep & Ex & Ep & Ex & Ep \\
\hline Item means & 7.450 & 7.342 & 6.600 & 6.700 & 8.280 & 8.000 & 1.680 & 1.300 & .202 & .120 \\
\hline $\begin{array}{l}\text { Item } \\
\text { Variances }\end{array}$ & 1.664 & 2.600 & .696 & 1.600 & 4.173 & 4.311 & 3.478 & 2.710 & .688 & .437 \\
\hline $\begin{array}{l}\text { Inter-item } \\
\text { Covariance's }\end{array}$ & .490 & 1.743 & -.327 & .785 & 2.380 & 2.967 & 2.706 & 2.182 & .149 & .150 \\
\hline $\begin{array}{l}\text { Inter-item } \\
\text { correlations }\end{array}$ & .303 & .682 & -213 & .383 & .859 & .881 & 1.072 & .498 & .039 & .010 \\
\hline
\end{tabular}


The above table (4.6) explains the mean of expectation and experiences of the respondent who participated in the questioner, to the research the researcher has used 50 questioner and 21 question scaling 1-9 where 1 is referred as less important and 9 is referred as most important, the questions are framed on the bases of SERVQUAL model. The average of the expectation of the overall questioners is shown 7.450 and experiences are taken into 7.342 which is mentioned as a item mean, minimum heading describes the least score of the overall question on the bases of expectation and experiences and the maximum shows the higher level of scores of the overall question on the bases of expectation and experiences, covariance describes the measure of difference between the two random question of expectation and experiences whereas correlations express the similarity between the two question of expectation and experiences.

\section{Item - Total Statistics Of Expectation}

\begin{tabular}{|l|l|l|l|l|l|}
\hline statement & $\begin{array}{l}\text { Scale } \\
\text { mean if } \\
\text { item } \\
\text { deleted } \\
\mathbf{1}\end{array}$ & $\begin{array}{l}\text { Scale } \\
\text { variance if } \\
\text { item } \\
\text { deleted }\end{array}$ & $\begin{array}{l}\text { Corrected item } \\
- \text { total } \\
\text { correlation }\end{array}$ & $\begin{array}{l}\text { Squared } \\
\text { multiple } \\
\text { correlation }\end{array}$ & $\begin{array}{l}\text { Cronbach's } \\
\text { Alpha if item } \\
\text { deleted }\end{array}$ \\
\hline $\mathbf{2}$ & 147.4600 & 723.111 & .741 & .935 & .977 \\
\hline $\mathbf{3}$ & 147.4800 & 722.091 & .739 & .985 & .977 \\
\hline $\mathbf{4}$ & 147.3200 & 706.304 & .789 & .935 & .976 \\
\hline $\mathbf{5}$ & 146.8400 & 698.341 & .767 & .959 & .977 \\
\hline $\mathbf{6}$ & 146.7600 & 706.513 & .882 & .984 & .975 \\
\hline $\mathbf{7}$ & 147.1200 & 706.434 & .790 & .969 & .976 \\
\hline $\mathbf{8}$ & 146.5800 & 705.473 & .855 & .990 & .976 \\
\hline $\mathbf{9}$ & 146.8200 & 706.844 & .841 & .975 & .976 \\
\hline $\mathbf{1 0}$ & 146.8400 & 705.239 & .867 & .990 & .975 \\
\hline $\mathbf{1 1}$ & 146.1800 & 704.355 & .901 & .983 & .975 \\
\hline $\mathbf{1 2}$ & 146.2600 & 726.809 & .762 & .956 & .976 \\
\hline $\mathbf{1 3}$ & 146.4200 & 714.616 & .853 & .983 & .976 \\
\hline $\mathbf{1 4}$ & 146.5600 & 714.986 & .861 & .966 & .976 \\
\hline $\mathbf{1 5}$ & 146.7200 & 724.124 & .898 & .990 & .976 \\
\hline $\mathbf{1 6}$ & 146.7000 & 720.459 & .846 & .982 & .976 \\
\hline $\mathbf{1 7}$ & 146.9200 & 716.606 & .803 & .943 & .976 \\
\hline $\mathbf{1 8}$ & 146.6200 & 727.751 & .773 & .988 & .976 \\
\hline $\mathbf{1 9}$ & 146.9200 & 721.504 & .724 & .973 & .977 \\
\hline $\mathbf{2 0}$ & 146.9800 & 721.816 & .878 & .956 & .976 \\
\hline $\mathbf{2 1}$ & 147.0600 & 730.915 & .716 & .940 & .977 \\
\hline & 147.0400 & 700.366 & .853 & .980 & .976 \\
\hline
\end{tabular}

The above table (4.7) explains that deleting of any statement in the guidelines of Cronbach's alpha which are near to zero or approximately zero will result in improving the validity and reliability of the final result in this particular case the lowest correlation is the statement number 20 which is resulting to (.716) therefore deleting this item will not provide any improved changes. Further in the last column even after deleting the correlated item of the Cronbach's alpha the score would be resulting more than the principle score (.920) which is minimum, the highest score in the above table would be statements $(1,2,4,18,20)$ which is holding the score of (.977). 9,10 statement is the lowest which can be deleted as its scoring (.975) which describes that even after deleting the unwanted correlation sore which is closer to zero i.e. 20 the Cronbach's alpha score would be more than the principle score i.e. 920 as the Cronbach's alpha score would be (.977) so it can be reliable. 
Item - Total Statistics Of Experience

\begin{tabular}{|l|l|l|l|l|l|}
\hline statement & $\begin{array}{l}\text { Scale } \\
\text { mean if } \\
\text { item } \\
\text { deleted }\end{array}$ & $\begin{array}{l}\text { Scale } \\
\text { variance if } \\
\text { item } \\
\text { deleted }\end{array}$ & $\begin{array}{l}\text { Corrected } \\
\text { item - total } \\
\text { correlation }\end{array}$ & $\begin{array}{l}\text { Squared } \\
\text { multiple } \\
\text { correlation }\end{array}$ & $\begin{array}{l}\text { Cronbach's } \\
\text { Alpha if item } \\
\text { deleted }\end{array}$ \\
\hline $\mathbf{1}$ & 149.3600 & 230.766 & .194 & .879 & .902 \\
\hline $\mathbf{3}$ & 149.8400 & 223.280 & .426 & .889 & .895 \\
\hline $\mathbf{4}$ & 149.3200 & 207.569 & .634 & .848 & .889 \\
\hline $\mathbf{5}$ & 149.3000 & 214.378 & .478 & .962 & .895 \\
\hline $\mathbf{6}$ & 148.7800 & 215.318 & .736 & .925 & .888 \\
\hline $\mathbf{7}$ & 149.2800 & 221.022 & .547 & .877 & .892 \\
\hline $\mathbf{8}$ & 148.4800 & 223.316 & .463 & .849 & .894 \\
\hline $\mathbf{9}$ & 148.7600 & 218.309 & .654 & .994 & .890 \\
\hline $\mathbf{1 0}$ & 148.1600 & 228.178 & .469 & .992 & .895 \\
\hline $\mathbf{1 1}$ & 148.2200 & 233.563 & .202 & .927 & .900 \\
\hline $\mathbf{1 2}$ & 148.8400 & 222.096 & .527 & .945 & .893 \\
\hline $\mathbf{1 3}$ & 148.3600 & 228.235 & .429 & .935 & .895 \\
\hline $\mathbf{1 4}$ & 149.5400 & 198.580 & .659 & .952 & .890 \\
\hline $\mathbf{1 5}$ & 149.0600 & 217.404 & .568 & .923 & .892 \\
\hline $\mathbf{1 6}$ & 148.8600 & 227.347 & .414 & .893 & .895 \\
\hline $\mathbf{1 7}$ & 149.4400 & 211.925 & .590 & .989 & .891 \\
\hline $\mathbf{1 8}$ & 148.8400 & 212.953 & .624 & .984 & .890 \\
\hline $\mathbf{1 9}$ & 148.8800 & 226.842 & .350 & .792 & .897 \\
\hline $\mathbf{2 0}$ & 148.8200 & 218.559 & .725 & .946 & .889 \\
\hline $\mathbf{2 1}$ & 149.2600 & 218.319 & .596 & .971 & .891 \\
\hline & 149.4000 & 210.286 & .663 & .823 & .889 \\
\hline
\end{tabular}

The above table (4.8) explains that deleting of any statement in the guidelines of Cronbach's alpha which are near to zero or approximately zero will result, in improving the validity and reliability of the final result in this particular case the lowest correlation is the statement number 1 which is resulting to (.194) therefore deleting this item will not provide any improved changes. Further in the last column even after deleting the correlated item of the Cronbach's alpha score the highest score in the above table would be statements (1) which is holding the score of (.902). 5 statement is the lowest which can be deleted as it scoring (.888) which describes that even after deleting the unwanted correlation score and Cronbach's alpha item which is closer to zero i.e. 5 the Cronbach's alpha score would be more than the principle score i.e. .920 as the Cronbach's alpha score would be (.902) so it can be reliable.

\section{Scale Statistics}

\begin{tabular}{|l|l|l|l|}
\hline & Mean & Variances & $\begin{array}{l}\text { Standard } \\
\text { deviation }\end{array}$ \\
\hline expectation & 154.1800 & 786.844 & 28.05075 \\
\hline experience & 156.4400 & 240.700 & 15.51452 \\
\hline
\end{tabular}

To analysis the gap between customer experience and expectation the researcher has used the statistics words to find the 'mean, median and standard deviation' in the below tables (4.3.3):

Mean Expectation score $=$ calculation of the expectation score i.e. total number of respondents who participated in the survey on the bases of expectation

Mean Experiences score $=$ calculation of the experiences score i.e. total number of respondents who participated in the survey on the bases of experiences

Gap score of mean = Mean Expectation score - Mean Experiences score (subtraction of expectation score with experience score) 
Findings Of Each Service Quality Statement

1. The bank has a state of the art, fast technology and modern equipment's

\begin{tabular}{|l|l|l|l|}
\hline statistic & Expectation & Experience & Gap Score \\
\hline Standard deviation & 6.7200 & 7.0800 & 0.36 \\
\hline Total Responses & 1.53915 & 1.36785 & \\
\hline
\end{tabular}

2. General facilities in the bank are visually appealing

\begin{tabular}{|l|l|l|l|}
\hline statistic & Expectation & Experience & Gap Score \\
\hline Mean & 6.7000 & 6.6000 & 0.1 \\
\hline Standard deviation & 1.56818 & 1.24540 & \\
\hline Total Responses & 50 & 50 & \\
\hline
\end{tabular}

3. The professional appearances of the bank's reception desk

\begin{tabular}{|l|l|l|l|}
\hline statistic & Expectation & Experience & Gap Score \\
\hline Mean & 6.8600 & 7.1200 & 0.26 \\
\hline Standard deviation & 1.84070 & 1.66157 & \\
\hline Total Responses & 50 & 50 & \\
\hline
\end{tabular}

4. When the bank promises to do something by a certain time, it does so

\begin{tabular}{|l|l|l|l|}
\hline statistic & expectation & experience & Gap Score \\
\hline Mean & 7.3400 & 7.1400 & 0.2 \\
\hline Standard deviation & 2.07620 & 1.67831 & \\
\hline Total Responses & 50 & 50 & \\
\hline
\end{tabular}

5. Does the bank employees show sincere interest in solving problems

\begin{tabular}{|l|l|l|l|}
\hline statistic & expectation & experience & Gap Score \\
\hline Mean & 7.4200 & 7.6600 & 0.24 \\
\hline Standard deviation & 1.65480 & 1.11776 & \\
\hline Total Responses & 50 & 50 & \\
\hline
\end{tabular}

6. The bank performs the service right the first time

\begin{tabular}{|l|l|l|l|}
\hline statistic & expectation & experience & Gap Score \\
\hline Mean & 7.0600 & 7.1600 & 0.1 \\
\hline Standard deviation & 1.83403 & 1.13137 & \\
\hline Total Responses & 50 & 50 & \\
\hline
\end{tabular}

7. ATMs and deposit machine operates stably

\begin{tabular}{|l|l|l|l|}
\hline Statistic & expectation & experience & Gap Score \\
\hline Mean & 7.6000 & 7.9600 & 0.36 \\
\hline Standard deviation & 1.72615 & 1.15987 & \\
\hline Total Responses & 50 & 50 & \\
\hline
\end{tabular}

8. The behaviour of employees in the bank instil confidence in you

\begin{tabular}{|l|l|l|l|}
\hline Statistic & Expectation & experience & Gap Score \\
\hline Mean & 7.3600 & 7.6800 & 0.32 \\
\hline Standard deviation & 1.72331 & 1.09619 & \\
\hline
\end{tabular}


9. You feel secure in your transactions with the bank

\begin{tabular}{|l|l|l|l|}
\hline Statistic & Expectation & experience & Gap Score \\
\hline Mean & 7.3400 & 8.2800 & 0.94 \\
\hline Standard deviation & 1.70964 & 0.83397 & \\
\hline Total Responses & 50 & 50 & \\
\hline
\end{tabular}

10. Are employees of the bank consistently polite

\begin{tabular}{|l|l|l|l|}
\hline statistic & expectation & experience & Gap Score \\
\hline Mean & 8.0000 & 8.2200 & 0.22 \\
\hline Standard deviation & 1.66599 & 0.99571 & \\
\hline Total Responses & 50 & 50 & \\
\hline
\end{tabular}

11. Employees in the bank have the knowledge / awareness to answer your question

\begin{tabular}{|l|l|l|l|}
\hline statistic & expectation & experience & Gap Score \\
\hline Mean & 7.9200 & 7.6000 & 0.32 \\
\hline Standard deviation & 1.41190 & 1.10657 & \\
\hline Total Responses & 50 & & \\
\hline
\end{tabular}

12. Employees in the bank are always willing to help you

\begin{tabular}{|l|l|l|l|}
\hline statistic & expectation & experience & Gap Score \\
\hline Mean & 7.7600 & 8.0800 & 0.32 \\
\hline Standard deviation & 1.53277 & 0.89989 & \\
\hline Total Responses & 50 & 50 & \\
\hline
\end{tabular}

13. Sufficient number of branches and ATMs

\begin{tabular}{|l|l|l|l|}
\hline statistic & expectation & experience & Gap Score \\
\hline Mean & 7.6200 & 6.9000 & 0.72 \\
\hline Standard deviation & 1.51037 & 2.04291 & \\
\hline Total Responses & 50 & 50 & \\
\hline
\end{tabular}

14. Informs exactly when services will be provided

\begin{tabular}{|l|l|l|l|}
\hline statistic & expectation & experience & Gap Score \\
\hline Mean & 7.4600 & 7.3800 & 0.08 \\
\hline Standard deviation & 1.26507 & 1.29189 & \\
\hline Total Responses & 50 & 50 & \\
\hline
\end{tabular}

15. Employees give prompt services

\begin{tabular}{|l|l|l|l|}
\hline statistic & expectation & experience & Gap Score \\
\hline Mean & 7.4800 & 7.5800 & 0.1 \\
\hline Standard deviation & 1.41767 & 0.99160 & \\
\hline Total Responses & 50 & 50 & \\
\hline
\end{tabular}

16. Never too busy to respond to the service requests

\begin{tabular}{|l|l|l|l|}
\hline Statistic & expectation & experience & Gap Score \\
\hline Mean & 7.2600 & 7.0000 & 0.26 \\
\hline Standard deviation & 1.57545 & 1.53862 & \\
\hline Total Responses & 50 & 50 & \\
\hline
\end{tabular}

17. Employees provides personal attention to the customer

\begin{tabular}{|l|l|l|l|}
\hline Statistic & expectation & experience & Gap Score \\
\hline Mean & 7.5600 & 7.6000 & 0.4 \\
\hline Standard deviation & 1.37262 & 1.41421 & \\
\hline
\end{tabular}


Total Responses

50

50

18. Does the bank provide convenient operating hours to all its customer

\begin{tabular}{|l|l|l|l|}
\hline Statistic & expectation & experience & Gap Score \\
\hline Mean & 7.2600 & 7.5600 & 0.3 \\
\hline Standard deviation & 1.61384 & 1.18080 & \\
\hline Total Responses & 50 & 50 & \\
\hline
\end{tabular}

19. The bank employees provide personal attention to the customer

\begin{tabular}{|l|l|l|l|}
\hline Statistic & expectation & experience & Gap Score \\
\hline Mean & 7.2000 & 7.6200 & 0.42 \\
\hline Standard deviation & 1.34012 & 0.98747 & \\
\hline Total Responses & 50 & 50 & \\
\hline
\end{tabular}

20. The bank has your best interests at heart

\begin{tabular}{|l|l|l|l|}
\hline Statistic & expectation & experience & Gap Score \\
\hline Mean & 7.1200 & 7.1800 & 0.06 \\
\hline Standard deviation & 1.39445 & 1.18992 & \\
\hline Total Responses & 50 & 50 & \\
\hline
\end{tabular}

21. The employees of the bank understand the need of their customer

\begin{tabular}{|l|l|l|l|}
\hline Statistic & expectation & experience & Gap Score \\
\hline Mean & 7.1400 & 7.0400 & 0.1 \\
\hline Standard deviation & 1.84070 & 1.47025 & \\
\hline Total Responses & 50 & 50 & \\
\hline
\end{tabular}

\section{The Gap Between Five Quality Dimensions Tangibility Dimension}

\begin{tabular}{|c|c|c|c|c|}
\hline statement & Service quality questions & $\begin{array}{l}\text { Mean } \\
\text { expectation }\end{array}$ & $\begin{array}{l}\text { Mean } \\
\text { experiences }\end{array}$ & $\begin{array}{l}\text { Gap } \\
\text { score }\end{array}$ \\
\hline 1 & $\begin{array}{l}\text { The bank has a state of the fast } \\
\text { technology and Modern equipment's }\end{array}$ & 6.7200 & 7.0800 & 0.36 \\
\hline 2 & $\begin{array}{l}\text { General facilities in the bank are } \\
\text { visually appealing }\end{array}$ & 6.7000 & 6.6000 & 0.1 \\
\hline 3 & $\begin{array}{l}\text { The professional appearances of the } \\
\text { bank's reception desk }\end{array}$ & 6.8600 & 7.1200 & 0.26 \\
\hline \multirow[t]{2}{*}{4} & $\begin{array}{l}\text { When the bank promises to do } \\
\text { something by a certain time, it does } \\
\text { so }\end{array}$ & 7.3400 & 7.1400 & 0.2 \\
\hline & Total score of tangibility & 27.6200 & 27.9400 & 0.3200 \\
\hline
\end{tabular}

\section{Tangibility \\ Reference required}

The tangible aspects of the Barclays bank, Chester service provided to the international students are analyzed on the basis of the respondents. The services provided to the customer, which are not reaching the satisfactory level of the customer than the services offered are dis-satisfactory. In the above table 4.10 other than statement 1 and 3 which are scoring the positive score of $(0.36$ and 0.26$)$ have reached the expectation but not in large margin, the main aspects in those statement are modern technology in the banking sector at the present banking world and the third statement was on appearances of the bank employee who will be receiving their customers regularly, in these two aspects the bank has made an effort to satisfy the customer. The negative score statement is 2 and 4 scoring $(0.1 \& 0.2)$ and the statements were on visually appealing like the help desk, direct deposit machines and mini statement machine and the other statement is banking 
promises, these tangible dimensions are important to the customer who have urgent need and the satisfaction of the customer is also important as the margin is not larger in numbers, and it could be overcome with a suitable solution.

The below chart 4.1 showcases the numerical data in the below graphical model.

\section{Tangible Attributes}

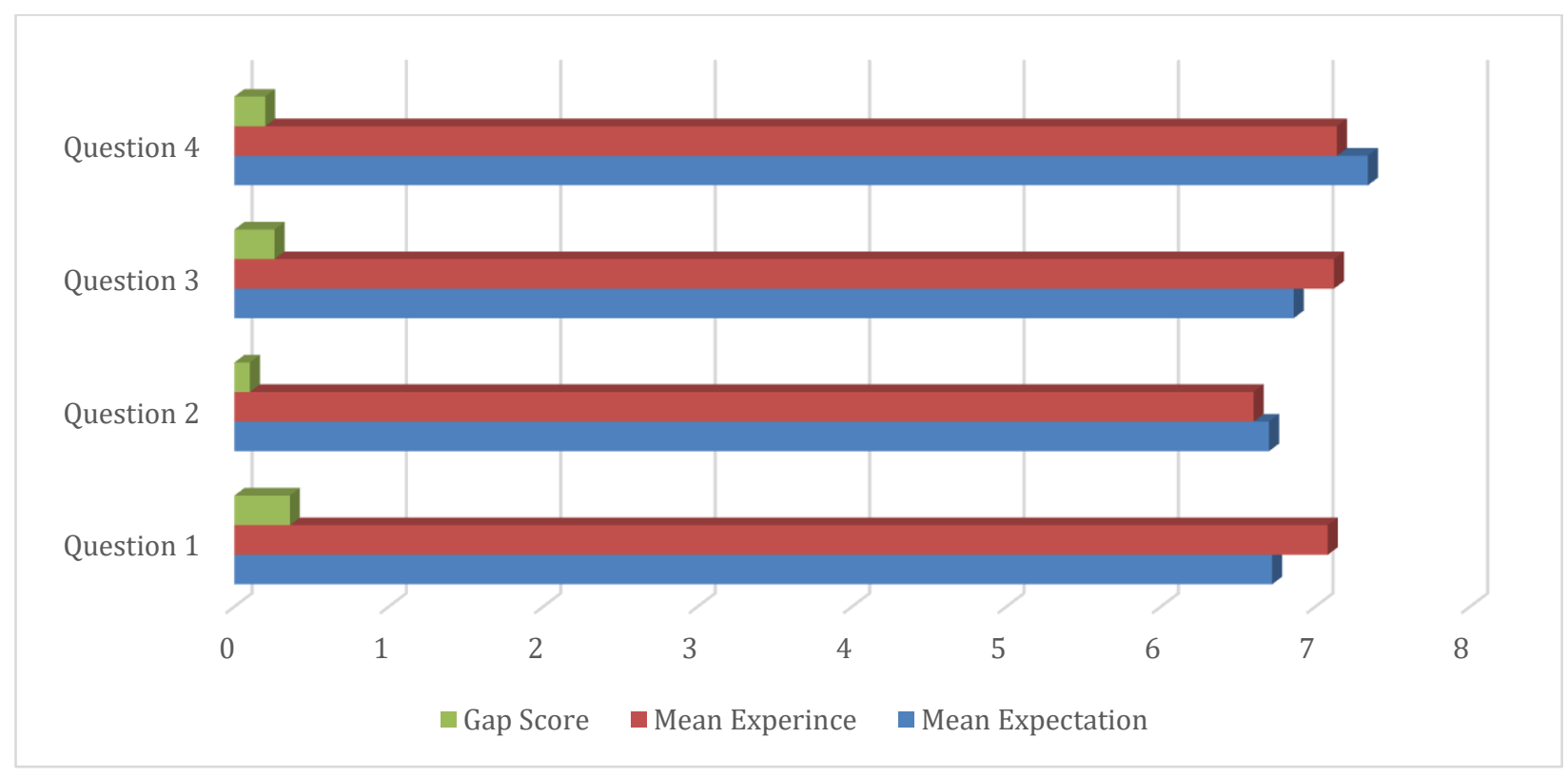

\section{Reliability Dimension}

\begin{tabular}{|c|l|l|l|l|}
\hline statement & Service quality questions & $\begin{array}{l}\text { Mean } \\
\text { expectation }\end{array}$ & $\begin{array}{l}\text { Mean } \\
\text { experiences }\end{array}$ & Gap score \\
\hline $\mathbf{5}$ & $\begin{array}{l}\text { Does the bank employees show } \\
\text { sincere interest in solving } \\
\text { problems }\end{array}$ & 7.4200 & 7.6600 & 0.24 \\
\hline $\mathbf{6}$ & $\begin{array}{l}\text { The bank performs the service } \\
\text { right the first time }\end{array}$ & 7.0600 & 7.1600 & 0.1 \\
\hline $\mathbf{8}$ & $\begin{array}{l}\text { ATMs and deposit machine } \\
\text { operates stably }\end{array}$ & 7.6000 & 7.9600 & 0.36 \\
\hline $\mathbf{9}$ & $\begin{array}{l}\text { The behaviour of employees in the } \\
\text { bank instil confidence in you }\end{array}$ & 7.3600 & 7.6800 & 0.32 \\
\hline & $\begin{array}{l}\text { You feel secure in your } \\
\text { transactions with the bank }\end{array}$ & 7.3400 & 8.2800 & 0.94 \\
\hline & \begin{tabular}{l} 
Total score of Reliability \\
\hline
\end{tabular} & $\mathbf{3 6 . 7 8}$ & $\mathbf{3 8 . 7 4}$ & $\mathbf{1 . 9 6}$ \\
\hline
\end{tabular}




\section{Reliability}

Reliability is an aspect of validity, and a tool for measuring the concreteness of the services is been provided by the service provider, and this dimension explains the reliability of the bank on their customers, from the above findings the researcher concludes that relatability of the Barclays bank Chester has proved the required services to the international customer, we can see the reliability of the customer towards the bank are satisfied regarding the dimension of reliability, thus according to the customers, the bank is effectively reliable for the services they provide and can be trusted with all the services.

There is a positive gap between the expectation and experiences of the international students as the above result shows a $1.96 \%$ gap score, which is an advantage for the bank. The below chart showcases the numerical data in the below graphical model.

\section{Reliability Attributes}

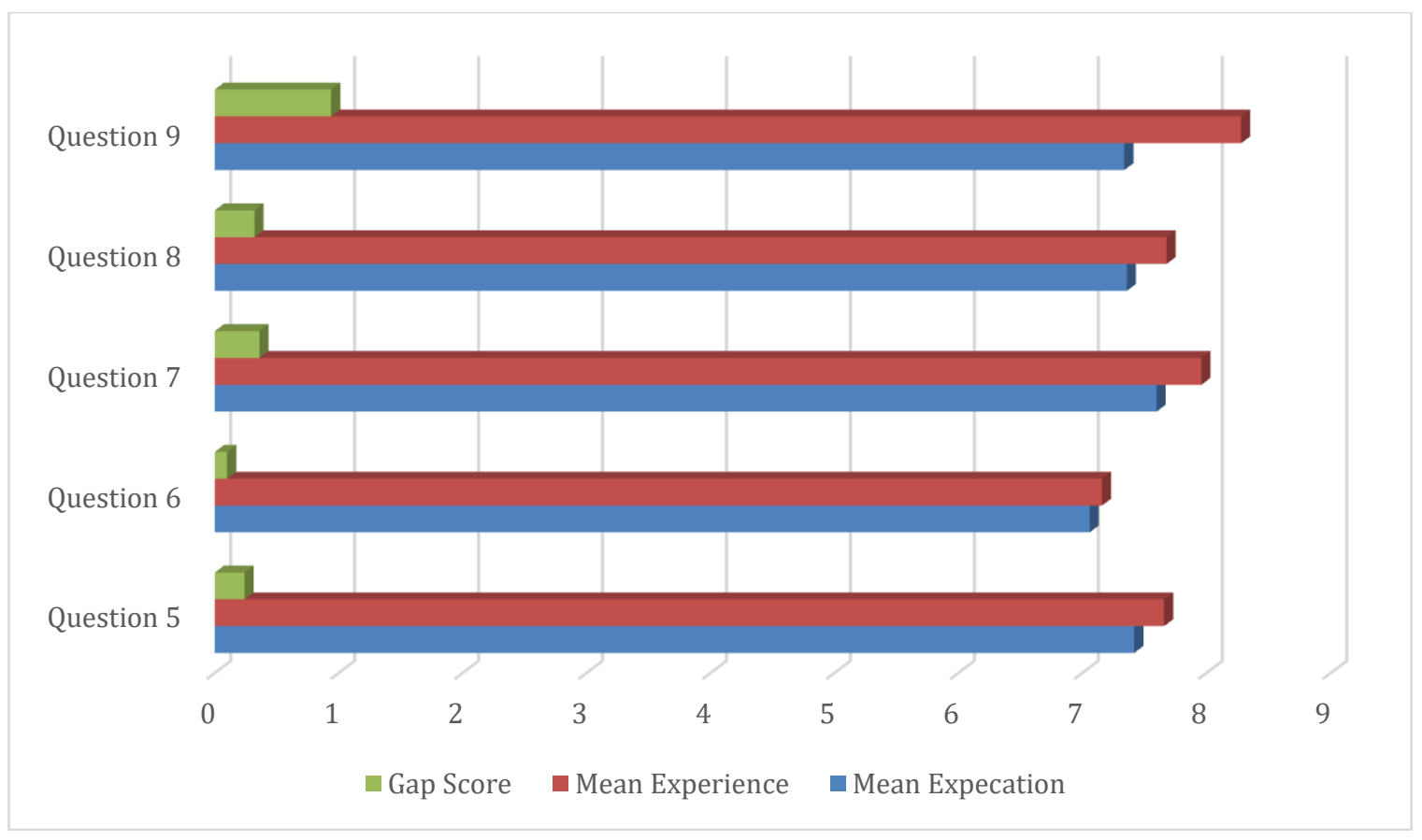

\section{Responsiveness Dimension}

\begin{tabular}{|c|l|l|l|l|}
\hline Statement & Service quality questions & $\begin{array}{l}\text { Mean } \\
\text { expectation }\end{array}$ & $\begin{array}{l}\text { Mean } \\
\text { experiences }\end{array}$ & Gap score \\
\hline $\mathbf{1 0}$ & $\begin{array}{l}\text { Are employees of the bank } \\
\text { consistently polite }\end{array}$ & 8.0000 & 8.2200 & 0.22 \\
\hline $\mathbf{1 1}$ & $\begin{array}{l}\text { Employees in the bank have the } \\
\text { knowledge / awareness to answer } \\
\text { your question }\end{array}$ & 7.9200 & 7.6000 & 0.32 \\
\hline $\mathbf{1 2}$ & $\begin{array}{l}\text { Employees in the bank are always } \\
\text { willing to help you }\end{array}$ & 7.7600 & 8.0800 & 0.32 \\
\hline & Total score of & $\mathbf{2 3 . 6 8}$ & $\mathbf{2 3 . 9 0}$ & $\mathbf{0 . 2 2}$ \\
\hline
\end{tabular}




\section{Responsiveness}

This dimension explains the effectiveness and the speed of response provided by the bank to the customers where responsiveness aspect relates to the expected knowledge of the bank to their respective customers. The questions were designed to judge the bank's attitude in the way of communication or response to the international customers. The questions further judges three aspects in respective service delivery which are politeness of the employees while delivering the services, the respective knowledge of the right resources and queries of customers, and a prepared attitude in helping the consumers.

From the above table it can be seen that there is not much variance between the mean of expectation and experience, which can be analysed as a slightly positive response of customers towards this dimension in the statement 10 and 12 which hold the satisfaction gap of 0.22 and 0.32 which is positive.

The negative gap in the unsatisfied statement is 11 which has the gap of 0.32 which has to be overlooked by the bank in recovering the problems.

The below chart 4.3 showcases the numerical data in the below graphical model.

\section{Responsiveness Attributes}

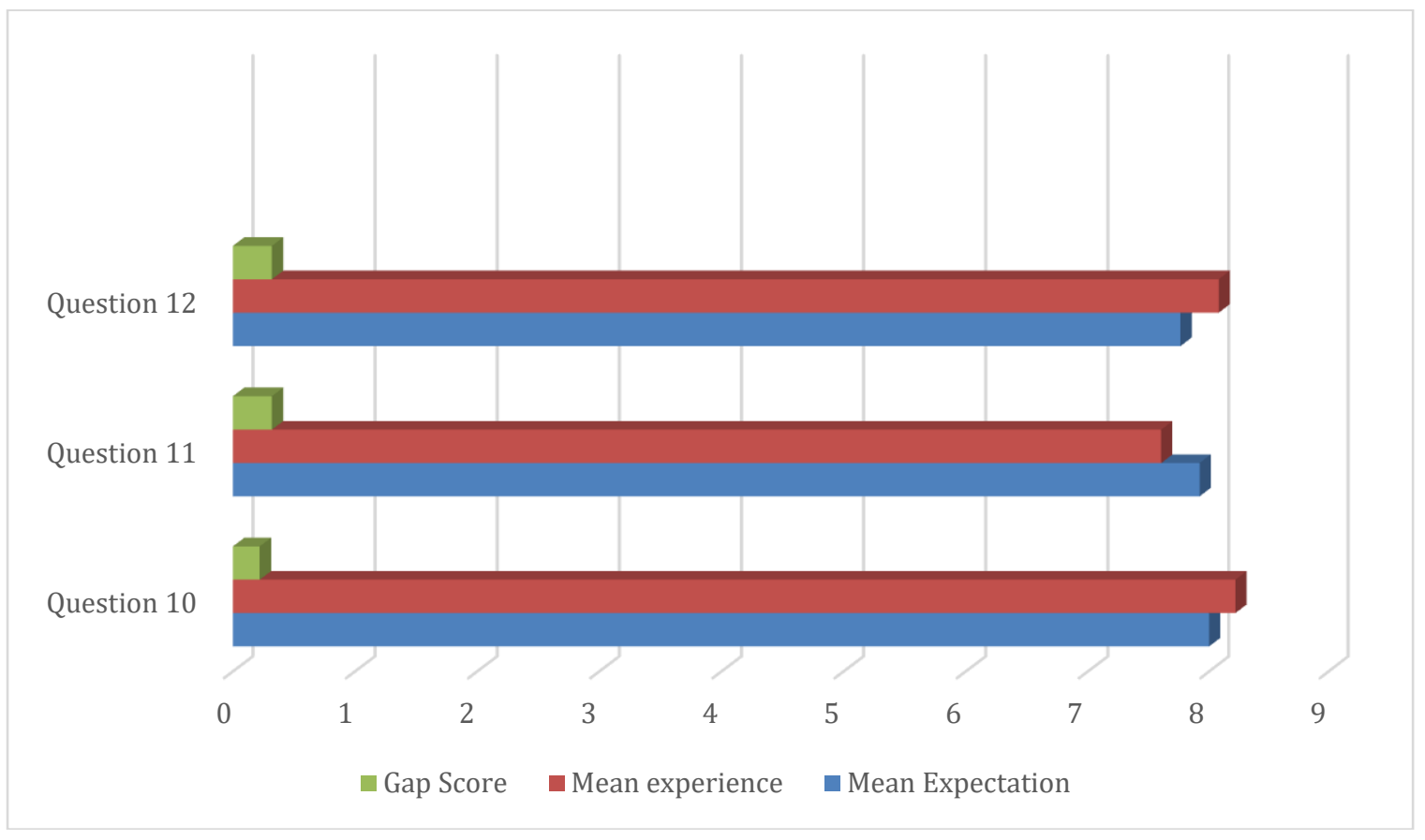

\section{Assurances Dimension}

\begin{tabular}{|c|l|l|l|l|}
\hline Statement & Service quality questions & $\begin{array}{l}\text { Mean } \\
\text { expectation }\end{array}$ & $\begin{array}{l}\text { Mean } \\
\text { experiences }\end{array}$ & $\begin{array}{l}\text { Gap } \\
\text { score }\end{array}$ \\
\cline { 2 - 5 } & $\begin{array}{l}\text { Sufficient number of branches and } \\
\text { ATMs }\end{array}$ & 7.6200 & 6.9000 & 0.72 \\
\hline $\mathbf{1 4}$ & $\begin{array}{l}\text { Informs exactly when services will be } \\
\text { provided }\end{array}$ & 7.4600 & 7.3800 & 0.08 \\
\hline $\mathbf{1 5}$ & Employees give prompt services & 7.4800 & 7.5800 & 0.1 \\
\hline $\mathbf{1 6}$ & $\begin{array}{l}\text { Never too busy to respond to the } \\
\text { service requests }\end{array}$ & 7.2600 & 7.0000 & 0.26 \\
\hline
\end{tabular}




\begin{tabular}{|l|l|l|l|l|}
\hline & Total score of & $\mathbf{2 9 . 8 2}$ & $\mathbf{2 8 . 8 6}$ & $\mathbf{0 . 9 6}$ \\
\hline
\end{tabular}

\section{Assurances}

This dimension explains about the assurances which is a sense of surety in an individual on the occasion of putting their trust is a certain entity.

The assurance dimension has achieved a positive satisfaction in most of the above mentioned questions, except question 15 which shows a positive rise of 0.1 score which cannot be mentioned as an effective satisfaction level. The other 3 above statements which as the negative satisfaction score which explain that the customer of Barclays bank are not getting the right amount of assurance which has to be delivered by the service provider.

The below chart 4.4 showcases the numerical data in the below graphical model.

\section{Assurances Attributes}

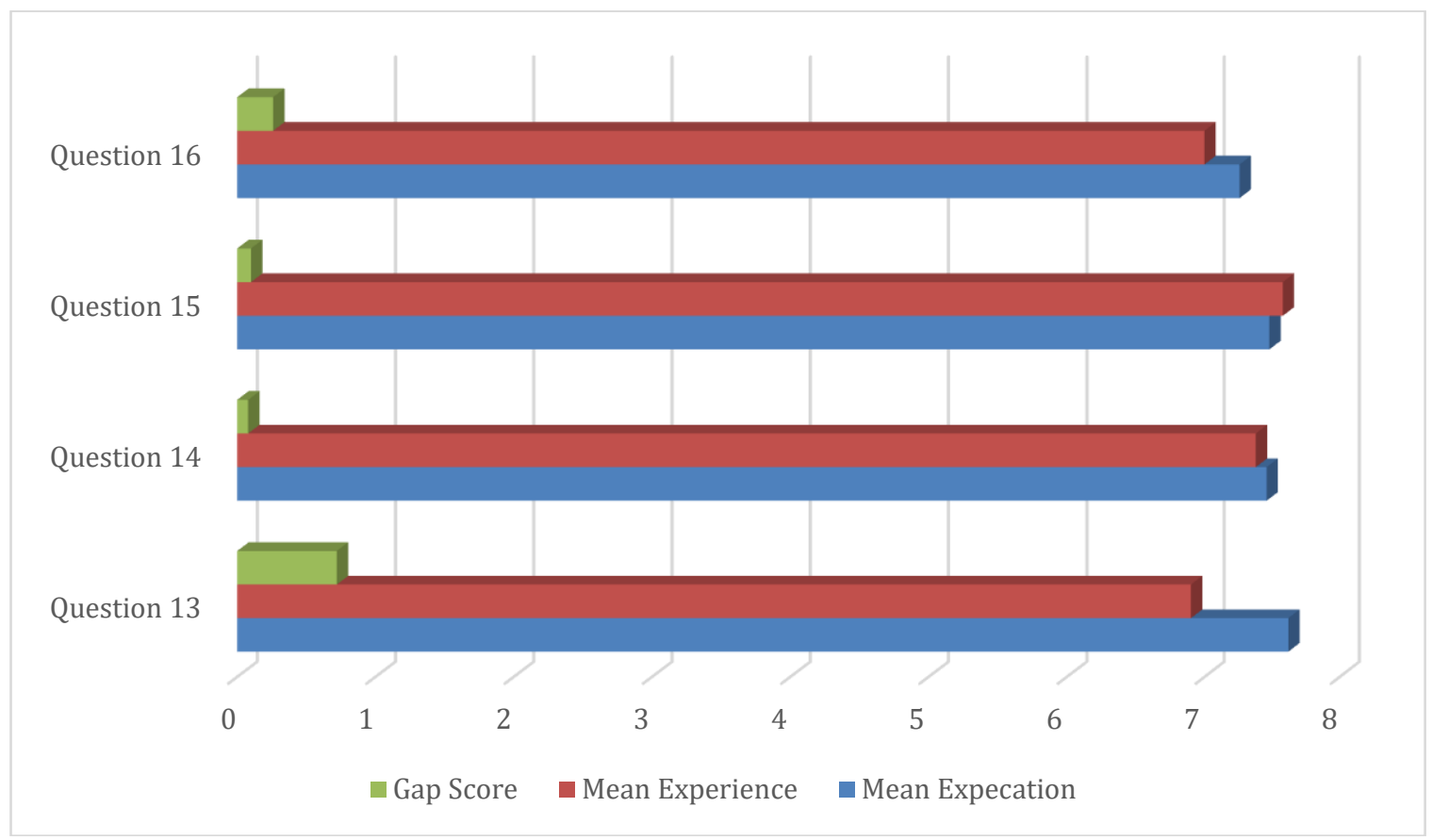

\section{Empathy Dimension}

\begin{tabular}{|c|c|c|c|c|}
\hline Statement & Service quality questions & $\begin{array}{l}\text { Mean } \\
\text { expectation }\end{array}$ & $\begin{array}{l}\text { Mean } \\
\text { experiences }\end{array}$ & $\begin{array}{l}\text { Gap } \\
\text { score }\end{array}$ \\
\hline 17 & $\begin{array}{l}\text { Employees provides personal } \\
\text { attention to the customer }\end{array}$ & 7.5600 & 7.6000 & 0.4 \\
\hline 18 & $\begin{array}{l}\text { Does the bank provide convenient } \\
\text { operating hours to all its customer }\end{array}$ & 7.2600 & 7.5600 & 0.3 \\
\hline 19 & $\begin{array}{l}\text { The bank employees provide } \\
\text { personal attention to the customer }\end{array}$ & 7.2000 & 7.6200 & 0.42 \\
\hline 20 & $\begin{array}{l}\text { The bank has your best interests at } \\
\text { heart }\end{array}$ & 7.1200 & 7.1800 & 0.06 \\
\hline 21 & $\begin{array}{l}\text { The employees of the bank } \\
\text { understand the need of their } \\
\text { customer }\end{array}$ & 7.1400 & 7.0400 & 0.1 \\
\hline
\end{tabular}




\begin{tabular}{|l|l|l|l|l|}
\hline & Total score of & $\mathbf{3 6 . 2 8}$ & $\mathbf{3 7}$ & $\mathbf{0 . 7 2}$ \\
\hline
\end{tabular}

\section{Empathy}

This dimension gives an insight into the personal attentiveness and care of the staff of Barclays towards international customers. The above statements show the positive gap in 17,18,19,20 which is $0.4,0.3,0.42$, and 0.06. Which shows that the bank staff is upfront in handling personal queries of these customers. The negative satisfaction of the Barclays bank was only one statement number 21 it has a gap of 0.1 , which was about the understanding customer requirement, or needs, which are essential to the banking sector to make their customer satisfied, so the Barclays bank has to make a proper suitable decision on overcoming the problem.

\section{Empathy Attributes}

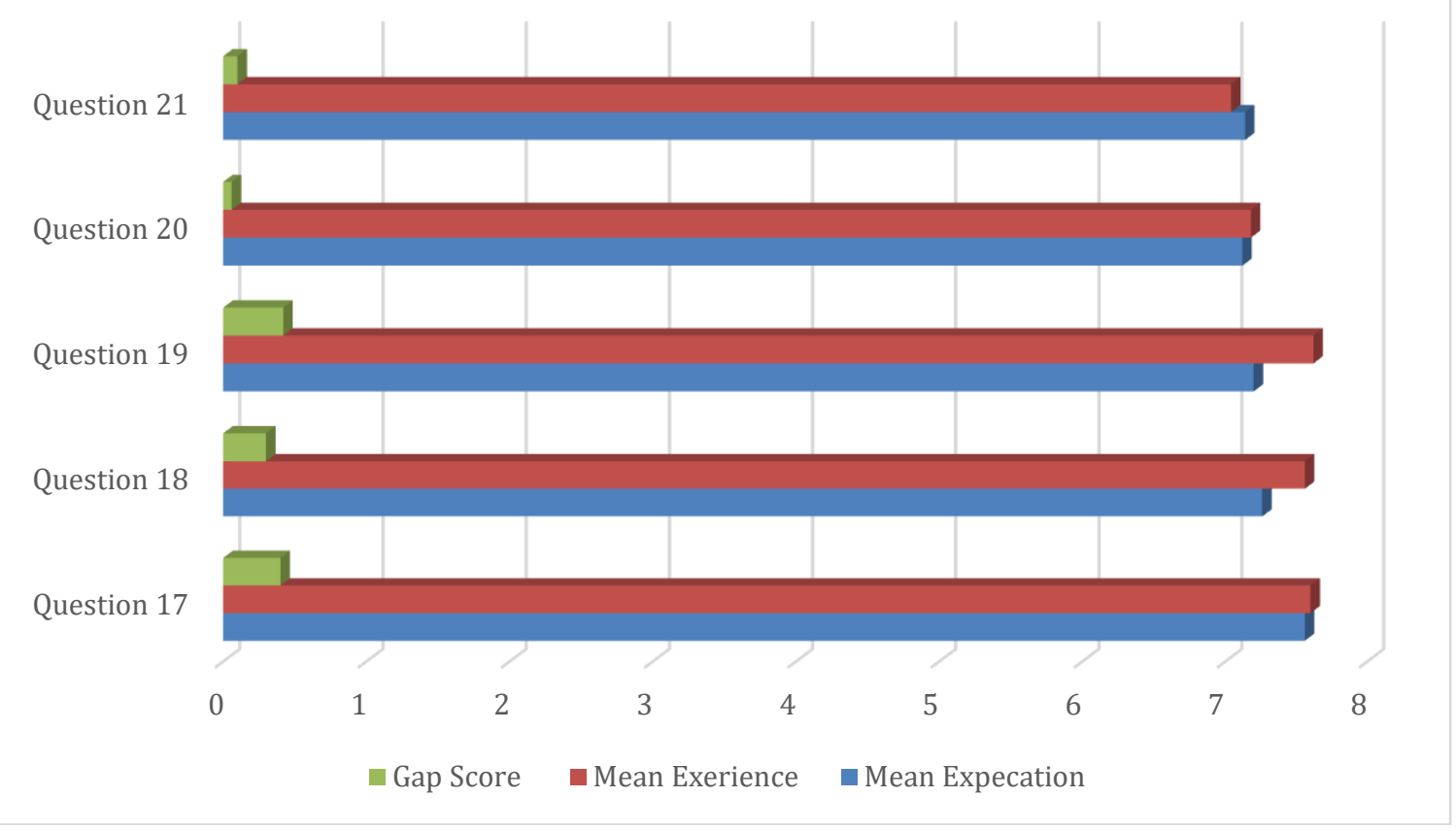

\section{Overall Service Quality Dimension}

\begin{tabular}{|l|l|l|l|}
\hline Service quality Attributes & Mean expectation & Mean experiences & Gap score \\
\cline { 2 - 4 } & 27.62 & 27.94 & 0.32 \\
\hline Reliability & 36.78 & 38.74 & 1.96 \\
\hline Responsiveness & 23.68 & 23.90 & 0.22 \\
\hline Assurances & 29.82 & 28.86 & 0.96 \\
\hline Empathy & & 37 & 0.72 \\
\hline Total Score & 36.28 & $\mathbf{1 5 6 . 4 4}$ & $\mathbf{2 . 2 6}$ \\
\hline
\end{tabular}




\section{Overall Service Quality Dimension}

The overall findings from the five service quality dimensions shows the positive responses of customers which in turn means that the customers are satisfied in every aspect of service quality presentation, empathy tangibility has a positive gap of 0.32 , reliability has positive score of 1.96 , responsiveness has a positive score of 0.22 , empathy has positive score of 0.72 . The positive gap of the four dimension which is not in bigger margin, but the Barclays banks has made an excellent effort in reaching the international customer satisfaction level. But the assurance service dimension which has got a negative score of 0.96, which explains the assurances given to the customer might not be filled by the bank to their international customer, this tells that the customer had more expectation in the assurance on the bank in their banking aspects.

The below chart 4.6 showcases the numerical data in the below graphical model.

\section{Overall Service Quality Attributes}



\section{Conclusions}

\section{Introduction:}

In the following chapter the researcher interprets the research findings, and draws out the conclusion around the subject matter and the research question and the objectives. This chapter critically evaluates the findings and the methodology adopted. It also covers limitations to the study and further research opportunities.

\section{Critical Evaluation Of Adopted Methodology:}

The researcher has adopted quantitative research to the study, which explains the customer service gap between experience and expectation of Barclays bank Chester, the researcher has adopted the survey method on the bases of SERVQUAL model to analysis the gap between experience and expectation. According to Cohen, Manion \& Morrison (2003) to understand the company or the services organisation the suitable way is to adopt a quantitative method which would help in empathetic internal and external factors of the organisation service and their employees, that makes the researcher to understand the level of service provided in the positivist practice way.

The service quality has a five dimension which covers the whole organisation from the service provided to the services provider, this helps in calculating the services in a particular level of the service stages, the researcher had made an required study on all the methods of research and presented the study on the following method to make the research more effective and to understand the research topic at the fullest extent.

\section{Analysis About Each Reach Objectives}


The researcher as made two research aims to understand the research topic and to make the research more effective the research aims are mentioned below:

\section{AIM 1: Identifying the GAP between services expected and services received by an international student in Chester from Barclays bank.}

The main object of this aim is to identify the level of the gap which is occurring between the expectation and experience of the service provided, so the researcher has adopted the five service dimension to know the gap on the bases of each dimensions.

\section{Tangibility Gap In Service Quality}

The customer visiting the bank in the process of service is tangible as the place, electronic instruments, employees are tangible in nature, and in other word's people visits bank for service with the main objective to avail the service where the service delivered on the requirement of the customer needs and requirements (Strydom, 2004). The table 4.11 give the positive score of 0.32 which is acceptable as the services on the bases of tangibility are fairly acceptable by the international students, the statement 1 holds about the technology that is used inside the bank as the respondents has given 0.36 positive individual score for this statement which indicates that the customer are fairly accepting the services, in further they have to provide easy access to this technologies which will increases in more positive gap, second statement explains quick facilities like pay cheques and statement view machine are faster service provider and it has to be improved in by adding easy access to cash pay machine rather standings for longer period of time in the queue, the third statement about the employees appearances in the disk which has a positive score, the fourth statement is about the promises of the services inside the bank has a negative score of 0.2 which has to be reduced by fulfilling the promise in providing additive services to the customer.

\section{Reliability Gap In Service Quality}

Relying on the service provider for the service which is most common in the service sector, in this research the reliability score of Barclays has come positive of 0.94 overall and also positive in each particular statement which explains that the service provided are accepted and quality of the services can be seen in this dimension. This indicates that make the customer wish to operate their services with the bank in the future

As the gap score is not large, the bank has to improve their services to satisfy their customer and to create the positive scores.

\section{Responsiveness Gap In Service Quality}

Responsiveness is the enthusiasm of the service provider, if the services provider loses his or her enthusiasm then the level of services will also reduce, this will result in negative opinion in the customer's mind.

In the surrey question politeness and willing to helping are in positive scores with 0.22 and 0.32 and knowledge of answering the customer's question which falls on the negative side with the score of 0.32 , the overall score is 0.22 positive. A better way to overcome the problem is to provide more skill training to gain knowledge in banking function, this makes the bank to gain the positive score gap.

\section{Assurances Gap In Service Quality}

Trust is a very important factory which can hold the customer to access the service, as a result the service provider has to give full trust in his/her services and knowledge in services and solving the customer's problems, these are important to maintain good assurance with the customer.

In this dimension the Barclays banks gained positive score only in one statement with 0.1 which is bad to the banking company as it leads to loss of customers, rest three statements scored negative score where the overall score fall under 0.96 which is large indicating that the bank has to give more assurance to its customers to get a positive score.

\section{Empathy Gap In Service Quality}

This dimension is about the services provider attention towards their customer, these qualities are important as the service receiver will not be pleased if the quality of the services does not reaches his/ her expectations. The employees of the Barclays bank has provided a better attention towards the service 
delivery to the customer, this explains that the dimension has got a positive score of 0.72 overall and one negative score of 0.1 with less margin, if the company provides more quality services and can understand the needs of the customer then they can hold complete positive score in this dimension.

\section{AIM 2: Measuring service quality of the Barclays bank in respect to their services provided to international students in Chester. The Standard of services provided.}

The banking sector in the present century has grown rapidly and the banking companies are adopting various services in attracting the customer to opt them, as a result the competition between the banks has grown to a higher level. In this particular survey we can see the Barclays bank has made good effort in providing the service to the customer by understanding the requirement of the customer need and the process of giving services to the customer are rendered systematically. Establishing the technology in providing the service to make the services reach faster and more effectively, this has resulted in the bank to gain positive responses in all the dimension but there are negative score in the few statement. The positive score don't show higher margin specifying the bank to improve in the services provided before these positive gaps convert into negative gaps in the near future.

\section{Analysis Of Research Question}

The questions were framed to understand the gap between the expectation and experiences for finding this SERVQUAL model tool is used, and the question framed on the dimension of five service quality dimension. The scoring was done on the bases of scaling method from 1 to 9 where 1 was least important and 9 was most important and there was also pilot testing implemented in the survey question to understand the customer understandings and the necessity of the finding the gap was suitable with questions tested at this process, later seeing the pilot testing results which was circulated to 5 respondents, later correction were made by having discussion with the supervisor. According to various authors and the designer of the SERVQUAL model Parasuraman et al., (1985) this method of research will give the result of present opinion of the customers which Are Faces By Them And Depending On Each Individual Customer Experiences.

\section{Overall Conclusion}

The main object of this research is to examine the gap between expectation and expectation of the international students by adopting the SERVQUAL model and five dimension of services quality, the results were calculated on Cronbach's alpha method which had a score of 0.978 where the reliability score was 0.920 which describe that the survey method was reliable and the individual gap score of each statement was shown in the table 4.3.3 and the overall score of expectation is 154.18 and experience is 156.44 which has an positive gap score of 2.26 which specify that by this particular method the researcher was able to find the gap between expectation and experiences.

Overall all the dimensions has a positive score but if we are viewed individual according to the statement there are a few negative score which has to be looked into to make the overall gap score to hold higher positive score, suggestions to the bank needs to provide skill developing program to gain more productive services and to gain more knowledge about the services that the banks could provide when the customer are in need or to get higher customer satisfy, detailed research on the improvement of the customer satisfaction program of the service the Barclays bank Chester can improve in a level of delivering service quality.

\subsection{Limitations of Study}

This research has viewed the gap between customer expectation and experience of the international student, the limitation of this research is that the researcher has taken set of framed topic in finding the set of specified gap of only international students Chester, due to less time and less completion on the topic the researcher has chosen this set of selected respondent and region boundary research topic. The respondents to the questioners were 50 due short research period and reluctance of the respondents the researchers could collect back those many respondents.

\subsection{Opportunities For Further Research}

In the above overall conclusion and limitation in research we could propose that there are more chances for the further research, the method and the process projects the current satisfaction option of the customer and 
the set of respondents were only international students, so the next researcher can conduct a survey by including the overall student of their university or the customer in general of the Barclays bank to find out the gap of the that particular period of time of research, as the Barclays banks had less margin of positive score opinion from the customer, but in further research we can see the gap score. Depending on the duration gap, we can see if the Barclays bank has gained more satisfaction on its service are not by the next research.

\section{References}

[1] Abor, J. (2005). The effect of capital structure on profitability: an empirical analysis of listed firms in Ghana. The Journal of Risk Finance, 6(5), 438-445. http://dx.doi.org/10.1108/15265940510633505

[2] Ackrill, M., \& Hannah, L. (2001). Barclays. Cambridge, UK: Cambridge University Press

[3] Anderson, E. W. (1998). Customer Satisfaction and Word of Mouth. Journal of service research, 1(1), 5- 17. http://dx.doi.org/10.1177/109467059800100102.

[4] Babbie, E. (2004), the Practices of Social Research $\left(10^{\text {th }}\right.$ Ed.), California: Thomson Wadsworth

[5] Black, N.J., Lockett, A., Winklhofer. H., \& Ennew, C. (2001). The adoption of Internet financial service: A qualitative study. International Journal of Retail \& Distribution Management, 29(8), 390398

[6] Brink, A., \& Berndt, A. (2004). Customer relationship management \& customer service. Landsdowne, South Africa: Juta.

[7] Bryan, V., \& Wang, V. (2014). Technology Use and Research Approaches for Community Education and Professional Development. Hershey: IGI Global.

[8] Buttle, F (1994) "SERQUAL: review, critique, research agenda", European Journal of Marketing, Vol. 30 No. 1, pp. 8-32.

[9] Bryman, A. (2012). Social research methods. Oxford: Oxford University Press.

[10] Caruana, A. (2002), "service loyalty: the effects of service quality and the, mediating role of customer satisfaction", European journal of marketing, Vol.36 No.7/8,pp.811-28.

[11] Crouch, G. (2004). Consumer psychology of tourism, hospitality, and leisure. Wallingford, Oxon, UK: CABI Pub.

[12] Cohen, L., Manion, L., \& Morrison, K. (2003). Research methods in education. London: RoutledgeFalmer

[13] Cooper, D., \& Schindler, P. (2006). Business research methods. Boston: McGraw-Hill Irwin.

[14] Collins, H. (2010). Creative research: The theory and practice of research for the creative industries. Lausanne, Switzerland: AVA Publishing SA.

[15] Croxford, H., Abramson, F., \& Jablonowski, A. (2005). The art of better retail banking. Chi Chester, West Sussex, England: J. Wiley \& Sons.

[16] Dale, B., Wiele, A., \& Iwaarden, J. (2013). Managing quality. Hoboken, NJ: Blackwell Publishing.

[17] Delvin, S. J., Dong, H. K., \& Brown, M. (1993). Selecting a scale for measuring quality. Marketing research: A magazine of management and applications, 5(3), 12- 17.

[18] Denscombe, M. (2010). Ground rules for social research. Maidenhead, Berkshire, England: Open University Press/McGraw-Hill.

[19] Domingo, R. (2003). TQM IN BANKING. Rtdonline.com. Retrieved 10 October 2015, from http://www.rtdonline.com/BMA/BSM/7.html

[20] Eriksson, L.T., \& Wiederscheim-Paul, F. (1997). Att Utreda, Forska och Rapportera. Malmo: Liber Ekonomi

[21] Essvale Corporation Limited, (2007) Business Knowledge for IT in Retail Banking: A Complete Handbook for IT Professionals. (p. 05). Newtown place, London.

[22] Gilmore, A. (2003). Services marketing and management. London: Sage Publications.

[23] Garten, E. D. William, D.E. Nyce, J. M., \& Golden, J. (2008). Advances in library administration and organisation. Bingley, United Kingdom: Emerald Group Publishing Limited.

[24] Gaster, L. (1995), Quality in public service, Open University Press Buckingham.

[25] Gungor, H. (2007). Observing and registering emotional satisfaction of consumer contacts. Amsterdam: Amsterdam university press.

[26] Hardy, M., \& Bryman, A. (2009). Handbook of data analysis. London: SAGE Publications. 
[27] Hayes, B. (2008). Measuring customer satisfaction and loyalty. Milwaukee, Wis.: ASQ Quality Press.

[28] Hernon, P., \& Altman, E. Assessing service quality.

[29] Iyengar, G. (2007). Introduction to banking. New Delhi: Excel Books.

[30] Johns, N., \& Lee-Ross, D. (1998). Research methods in service industry management. London: Cassell.

[31] Jolley, J. (2010). Introducing research and evidence-based practice for nurses. Harlow, England: Pearson Education.

[32] Jayawardhena, C., \& Foley, P. (2000). Changes in the banking sector - the case of Internet banking in the UK. Internet Research, 10(1), 19-31. http://dx.doi.org/10.1108/10662240010312048

[33] Kotler, P. (2000), Marketing Management ed., Prentice-hall, Englewood Cliffs, NJ.

[34] Kolakowski, L. (1972). Intellectuals and change. Cambridge, Mass: American Acad. of Arts and Sciences.

[35] Kumar, P. (2010). Marketing of hospitality and tourism services. New Delhi, India: Tata McGraw Hill Education.

[36] Malhotra, N.K. (2004). Marketing Research: An Application Orientation (3 ${ }^{\text {rd }}$ Ed.). New Jersey, us: Prentice-Hall, Inc.

[37] Malhotra, N., \& Birks, D. (2007). Marketing research. Harlow: Prentice Hall/Financial Times.

[38] Oliver, R. (2010). Satisfaction. Armonk, N.Y.: M.E. Sharpe.

[39] Muntermann, J. (2007). Event-Driven mobile financial Information-Services. Wiesbaden: Deutscher Universitäts-Verlag.

[40] Ostrom, A. Lacobucci, D. (1995), "consumer trade-off and the evaluation of services", journal of marketing, vol.59pp.17-28.

[41] Panneerselvam, R. (2006). Research Methodology, New Delhi, India: Prentice-Hall of India private limited

[42] Parasuraman, A., Zeithaml, V., \& Berry, L. (1988). SERVQUAL: a multiple-item scale for measuring customer perception of service quality. Journal of retailing, 64(1), 12-40.

[43] Rajendar, K. C. (2008). Research Methodology, New Delhi, India: APH publishing Corporation

[44] Rust, R. T., Oliver, R.L. (1994), Service Quality: New Directions in Theory and Practice, Sage, London.

[45] Saunders, M. K., Lewis, p. and Thornhill, a (2000), Research Methods for Business Students, New York: Prentice Hall

[46] Saunders, M. N. K., Lewis, P., \& Thornhill, A. (2009). Research Methods for Business Students (5th ed.), Harlow, United Kingdom: Prentice Hall Financial Times.

[47] Schiuma, G. (2011). Managing knowledge assets and business value creation in organizations. Hershey PA: Business Science Reference.

[48] Sekaran, U. (2003). Research methods for business. New York: John Wiley \& Sons.

[49] Shrader-Frechette, K. S. (1994). Ethics of Scientific Research. Maryland, United States of America: Rowan \& Littlefield Publishers, Inc.

[50] Singh, Y. K., \& Bajpai, R. B. (2008). Research Methodology: Techniques and Trends. New Delhi, India: APH Publishing Corporation.

[51] Stokes, P. (2011). Key concepts in business and management research methods. Hampshire, United Kingdom: Palgrave Macmillan Publishers Limited.

[52] Vinten, G. (2005). International journal of bank marketing for the financial services sector. Bradford, England: Emerald Group Pub.

[53] Violano, M., \& Van Collie, S. (1992). Retail banking technology. New York: Wiley.

[54] Weaver, K., \& Olson, J. K. (2006). Understanding paradigms used for nursing research. Journal of advanced nursing, 53(4), 459- 469.

[55] Willis, J. W. (2008). Qualitative Research Methods in Education and Educational Technology. United States of America: Information Age Publishing Inc.

[56] Wirtz, J., Chew, P., \& Lovelock, C. Essentials of services marketing.

[57] Yin, R. (1994). Case study research. Thousand Oaks: Sage Publications.

[58] Yin, R. (2003). Case study research. Thousand Oaks, Calif.: Sage Publications. 
[59] Zeithaml, V., Parasuraman, A., \& Berry, L. (1990). Delivering quality service. New York: Free Press.

[60] Zeithaml, V., \& Parasuraman, A. (2004). Service quality. Cambridge, Mass.: Marketing Science Institute.

[61] Zikmund, W.G (1991), Business Research Methods, $3^{\text {rd }}$ Ed. The Dryden Press, Chicago, IL 